\title{
Sistem Pendukung Keputusan Pemeriksaan Kondisi Peralatan Primer Gardu Induk Menggunakan Metode SAW Berbasis Mobile (Studi Kasus: Pt. Pln (Persero) Gitet Saguling)
}

\author{
Ai Musrifah ${ }^{1}$, Muhammad Faisal Firmansyah ${ }^{2}$ \\ Program Studi Teknik Informatika Fakultas Teknik \\ Universitas Suryakancana Cianjur \\ aimusrifah@unsur.ac.id ${ }^{1}$, faisal25051997@gmail.com²
}

\begin{abstract}
PT. PLN (Persero) is a company engaged in the electricity sector, which there is a level 1 CBM inspection checklist, namely the inspection condition of substation primary equipment. The problem that arises is that JARGI officers must write the checklist result data into a form (paper), then input into the PLN web application so that they have to work 2 times. To find out which equipment is the worst, a Decision Support System is needed that can facilitate data collection, assessment, and data reporting on the condition of primary substation equipment and make work more effective and efficient. Decision Support System (DSS) is part of an information system that is able to provide problem-solving and communication skills for problems with semi-structured and unstructured conditions. Making DSS needs a suitable method for solving problems that arise, where the method used in this study is the SAW (Simple Additive Weighting) method, namely the weighted addition method. Software engineering uses the waterfall paradigm and system modeling analysis uses UML (Unified Modeling Language). The results of the research with the existence of a decision support system for checking the condition of primary equipment for mobile-based substations using the SAW method found that the equipment that has the worst condition is PMT 7B1 R because it has a higher value with the final emergency result. So that it can make it easier to collect data, assess, and report data on the condition of substation primary equipment and make work more effective and efficient.
\end{abstract}

Keywords: Substation primary equipment, Decision Support System, SAW

\begin{abstract}
Abstrak
PT. PLN (Persero) adalah perusahaan yang bergerak dibidang kelistrikan dimana didalamnya terdapat kegiatan checklist CBM inspeksi level 1 yaitu pemeriksaan kondisi peralatan primer Gardu Induk. Permasalahan yang timbul adalah petugas JARGI harus menuliskan data hasil checklist kedalam formulir (kertas), lalu diinputkan kedalam aplikasi web milik PLN sehingga harus bekerja 2 kali. Untuk mengetahui peralatan yang paling buruk diperlukan sebuah Sistem Pendukung Keputusan yang dapat mudahkan dalam pendataan, assessment, dan pelaporan data kondisi peralatan primer gardu induk serta membuat pekerjaan menjadi lebih efektif dan efisien. Sistem Pendukung Keputusan (SPK) merupakan bagian dari sebuah sistem informasi yang mampu memberikan kemampuan pemecahan masalah maupun kemampuan pengkomunikasian untuk masalah dengan kondisi semi terstruktur dan tak terstruktur. Pembuatan SPK perlu sebuah metode yang cocok untuk pemecahan permasalahan yang timbul, dimana metode yang digunakan dalam penelitian ini adalah metode SAW (Simple Additive Weighting) yaitu metode penjumlahan terbobot. Rekayasa perangkat lunak menggunakan paradigma waterfall dan analisa permodelan sistem menggunakan UML (Unified Modelling Language). Hasil dari penelitian dengan adanya sistem pendukung keputusan pemeriksaan kondisi peralatan primer Gardu Induk berbasis mobile dengan menggunakan metode SAW didapat bahwa peralatan yang memiliki kondisi terburuk adalah PMT 7B1 R karena memiliki nilai yang lebih tinggi dengan hasil akhir darurat. Sehingga dapat mempermudah dalam pendataan, assessment, dan pelaporan data kondisi peralatan primer gardu induk serta membuat pekerjaan menjadi lebih efektif dan efisien.
\end{abstract}

Kata kunci: Peralatan primer gardu induk, Sistem Pengambilan Keputusan, SAW

\section{Pendahuluan}

Sistem Pendukung Keputusan (SPK) merupakan bagian dari sebuah sistem informasi. SPK atau Decision Support System (DSS) yaitu sebuah sistem yang mampu memberikan kemampuan pemecahan masalah maupun kemampuan pengkomunikasian untuk masalah dengan kondisi semi terstruktur dan tak terstruktur. Salah satu metode yang dapat digunakan dalam pembuatan SPK adalah metode SAW (Simple Additive Weighting) yaitu metode penjumlahan terbobot.

PT. PLN (Persero) adalah perusahaan yang bergerak dibidang kelistrikan dimana didalamnya terdapat kegiatan checklist CBM inspeksi level 1 yaitu pemeriksaan kondisi peralatan primer Gardu Induk. Permasalahan yang timbul adalah petugas JARGI harus menuliskan data hasil checklist 
kedalam formulir (kertas), kemudian diinputkan kedalam aplikasi web milik PLN sehingga harus bekerja 2 kali, serta belum ada Sistem Pendukung Keputusan untuk mengetahui peralatan yang paling buruk. Maka dari itu diperlukan Sistem Pendukung Keputusan untuk mempermudah dalam pendataan, assessment, dan pelaporan data kondisi peralatan primer gardu induk serta membuat pekerjaan menjadi lebih efektif dan efisien.

Dilihat dari uraian latar belakang di atas, dapat dirumuskan suatu rumusan masalah yaitu bagaimana merancang dan membuat suatu Sistem Pendukung Keputusan yang dapat memutuskan dalam penentuan kondisi peralatan primer gardu induk berbasis mobile dengan menggunakan metode SAW di PT. PLN (PERSERO) GITET Saguling.

Maksud penelitian ini adalah membuat sistem pendukung keputusan pemeriksaan kondisi peralatan primer gardu induk berbasis mobile dengan menggunakan metode SAW dengan tujuan yaitu sebagai berikut:

1. Mempermudah dalam pendataan kondisi peralatan primer gardu induk.

2. Mempermudah dalam melakukan assesment peralatan gardu induk.

3. Mempermudah sistem pelaporan data kondisi peralatan primer gardu induk.

4. Membuat pekerjaan menjadi lebih efektif dan efisien karena tidak perlu mengisi data kondisi peralatan di kertas.

5. Efisiensi pengguna karena Supervisor GI tidak perlu melakukan approval tetapi hanya menerima hasil akhir perangkingan.

\section{Metode Penelitian}

Metode penelitian yang digunakan penulis menggunakan beberapa tahapan, sebagai berikut :

a. Survey

Metode ini digunakan untuk mengetahui dan mempelajari kebutuhan sistem dari pihak organisasi.

b. Analisis

Untuk mencapai kebutuhan pengguna, maka penulis melakukan analisis proses yang sedang berjalan ke PT. PLN (PERSERO) GITET Saguling, sehingga penulis dapat mengusulkan sistem yang diharapkan sesuai dengan kebutuhan pengguna.

c. Tinjauan Pustaka

Dalam perancangan menyertakan daftar pustaka sebagai sumber acuan lain yang mendasari atau menjadi bahan pertimbangan dalam penyusunan penulisan. Daftar Pustaka merupakan daftar sejumlah buku acuan atau referensi lain yang bahan utama dapat berupa suatu hasil pemikiran ilmuwan, tulisan, baik tulisan ilmiah maupun non ilmiah.

d. Metode Perancangan Rekayasa Perangkat Lunak

Metode Perancangan Rekayasa Perangkat Lunak yang digunakan adalah paradigma Waterfall, paradigma cost mempunyai tahapan sistem yang terstruktur. Selain itu, paradigma atau metode ini sering digunakan dalam tahap perancangan sebuah sistem. Metode ini terdiri dari 5 tahap yaitu Communication, Planning, Modeling, Construction dan Deployment.

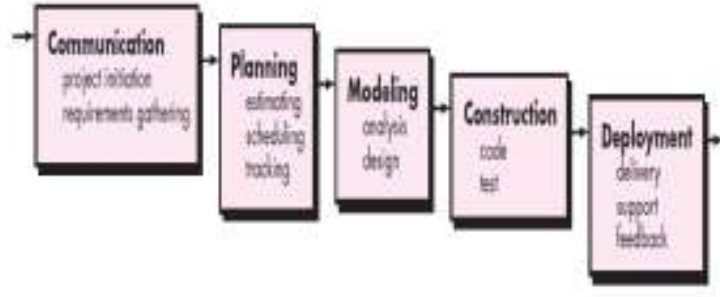

Gambar 1 Model Waterfall

Sumber [1]

Berikut ini rincian tahapan-tahapan dalam metode waterfall menurut Roger S Pressman :

a. Communication : Pada tahap ini peneliti melakukan survey ke pihak instansi dan melakukan wawancara untuk mendapatkan informasi dan data yang dibutuhkan penentuan kebutuhan dalam proses pengembangan sistem yang akan dibuat.

b. Planning : Melakukan perencanaan sistem yang akan dibuat sesuai dengan keinginan user. Dimulai dari sistem apa yang harus dirancang dan dibuat, kemudian dilanjutkan dengan penjadwalan proses pelaksanaan pengembangan sistem.

c. Modeling : Tahapan dimana pelaksanaan terhadap analisis sistem yang akan dibuat meliputi Analysis Modeling dan Design Modeling. Pada Analysis Modeling meliputi Scenario-Based Modelling dengan membuat Use Case Diagram dan Activity Diagram atau Swimlane Diagram, Data Modelling dengan membuat Class Diagram dan Entity Relationship Diagram serta Behavioral Modeling dengan membuat State Diagram dan Sequence Diagram. Pada Design Modeling meliputi Architectural Design dengan membuat struktur menu dan User Interface Design dengan membuat desain tampilan aplikasi yang akan dibuat.

d. Construction : Membuat aplikasi sesuai dengan perencanaan dan analisis dengan menggunakan bahasa pemrograman java pada aplikasi android studio serta melakukan testing aplikasi.

e. Deployment : Mengimplementasikan produk ke perusahaan atau instansi.

\section{Tinjauan Pustaka}

3.1 Konsep Dasar Sistem Pendukung Keputusan

Pada awalnya Turban dan Aronson, mendefinisikan sistem penunjang keputusan (Decision Support Systems - DSS) sebagai sistem yang digunakan untuk mendukung dan membantu pihak manajemen melakukan pengambilan keputusan pada kondisi semi terstruktur dan tidak terstruktur. Pada dasarnya konsep DSS hanyalah sebatas pada kegiatan membantu para manajer melakukan penilaian serta menggantikan posisi dan peran manajer [2]

Menurut [3] mengemukakan bahwa Terdapat dua model pengambilan keputusan, yaitu model sistem tertutup dan model sistem terbuka. a. Model Sistem Tertutup Model sistem tertutup dilandasi asumsi bahwa keputusan dapat diambil tanpa campur tangan dari lingkungan (luar) sistem, karena sistem pengambilan keputusan tidak dipengaruhi oleh lingkungan. Dalam hal ini sistem pengambilan keputusan dianggap: 1) Mengetahui semua alternatif tindakan untuk menanggapi permasalahan dengan segala konsekuensinya. 2) Memiliki metode untuk menyusun alternatif-alternatif sesuai prioritasnya. 3) Dapat memilih/menetapkan alternatif yang paling menguntungkan, misalnya dari segi laba, manfaat, dan 
lain-lain. b. Model Sistem Terbuka Model sistem terbuka dilandasi asumsi bahwa sistem pengambilan keputusan dan lingkungan memiliki hubungan saling pengaruh. Keputusan yang diambil akan berdampak terhadap lingkungan dan sebaliknya lingkungan juga berpengaruh terhadap sistem pengambilan keputusan. Dalam hal ini sistem pengambilan keputusan dianggap: 1) Hanya mengetahui sebagian saja dari alternatif-alternatif untuk menangani permasalahan dengan segala konsekuensinya. 2) Hanya dapat menyajikan sejumlah alternatif yang baik untuk menangani permasalahan, tetapi tidak dapat memilih/menetapkan alternatif yang paling menguntungkan. 3) Sekadar mempersilakan pemilihan alternatif terbaik untuk dilakukan oleh pijak diluar sisten sesuai dengan aspirasinya.

Menurut [4] bahwa kriteria penilaian dapat ditentukan sendiri sesuai dengan kebutuhan perusahaan.

\subsection{Pengertian Metode Simple Additive Weighting (SAW)}

Metode Simple Additive Weighting (SAW) sering juga dikenal istilah metode penjumlahan terbobot. Konsep dasar metode SAW adalah mencari penjumlahan terbobot dari rating kinerja pada setiap alternatif pada semua atribut [5]. Metode SAW membutuhkan proses normalisasi matriks keputusan (X) ke suatu skala yang dapat diperbandingkan dengan semua rating alternatif yang ada. Metode ini merupakan metode yang paling terkenal dan paling banyak digunakan dalam menghadapi situasi Multiple Attribute Decision Making (MADM). MADM itu sendiri merupakan suatu metode yang digunakan untuk mencari alternatif optimal dari sejumlah alternatif dengan kriteria tertentu.

3.3 Langkah Penyelesaian Simple Additive Weighting (SAW)

1. Menentukan kriteria-kriteria yang akan dijadikan acuan dalam pengambilan keputusan, yaitu $\mathrm{Ci}$.

2. Menentukan rating kecocokan setiap alternatif pada setiap kriteria.

3. Membuat matriks keputusan berdasarkan kriteria(Ci), kemudian melakukan normalisasi matriks berdasarkan persamaan yang disesuaikan dengan jenis atribut (atribut keuntungan ataupun atribut biaya) sehingga diperoleh matriks ternormalisasi R. 4. Hasil akhir diperoleh dari proses perankingan yaitu penjumlahan dari perkalian matriks ternormalisasi $\mathrm{R}$ dengan vektor bobot sehingga diperoleh nilai terbesar yang dipilih sebagai alternatif terbaik (Ai)sebagai solusi. Formula untuk melakukan normalisasi tersebut adalah :

\section{? $\frac{X_{0}}{\operatorname{Max} X_{9}}$ Jika j adalah atribut keuntungan (benefit)$$
r_{i=}=\{
$$ \\ $\frac{\operatorname{Min} x_{4}}{x_{1}}$ \\ Sika $j$ adalah atribut biaya (cost)}

Dimana :

$\mathrm{r}_{\mathrm{ij}}=$ rating kinerja ternormalisasi

$\mathrm{Max}_{\mathrm{ij}}=$ nilai maksimum dari setiap baris dan kolom

$\operatorname{Min}_{\mathrm{ij}}=$ nilai minimum dari setiap baris dan kolom

$\mathrm{X}_{\mathrm{ij}}=$ baris dan kolom dari matriks Dengan rij adalah rating kinerja ternormalisasi dari alternatif Ai pada atribut $\mathrm{Cj}$; i $=1,2, \ldots \mathrm{m}$ dan $\mathrm{j}=1,2, \ldots, \mathrm{n}$.

Nilai preferensi untuk setiap alternatif (Vi) diberikan sebagai :

$$
\mathrm{V}_{\mathrm{i}}=\sum_{\mathrm{j}=1}^{\mathrm{n}} \mathrm{w}_{\mathrm{j}} \mathbf{r}_{\mathrm{ij}}
$$

Dimana :

$\mathrm{V}_{\mathrm{i}}=$ Nilai akhir dari alternatif $\mathrm{w}_{\mathrm{j}}=$ Bobot yang telah ditentukan

$\mathrm{r}_{\mathrm{ij}}=$ Normalisasi matriks

Nilai Vi yang lebih besar mengindikasikan bahwa alternatif $A_{i}$ lebih terpilih.

\section{Hasil \& Pembahasan}

4.1 Analisis Metode SAW (Simple Additive Weighting) Dalam Penentuan Kondisi Peralatan Primer Gardu Induk

Tahapan metode SAW pada penentuan kondisi peralatan primer Gardu Induk :

1. Menentukan Kriteria Untuk Penentuan Kondisi Peralatan Primer Gardu Induk

Langkah awal untuk penentuan kondisi peralatan primer Gardu Induk dimulai dari analisa terhadap kriteria-kriteria yang dapat dijadikan tolak ukur terhadap sistem pendukung keputusan pemeriksaan kondisi peralatan primer Gardu Induk. Kriteria ini disusun berdasarkan karakteristik peralatan primer tersebut. Kriteria yang digunakan untuk pendukung keputusan ini adalah Tekanan Gas SF6 (K1), Tekanan Hidrolik (K2) dan Counter Kerja Pompa Hidrolik (K3) [6]

Tabel 1 Nilai Masing-masing Kriteria

\begin{tabular}{|c|c|c|c|}
\hline KODE & \multicolumn{3}{|c|}{ KRITERIA } \\
\cline { 2 - 4 } PERALATAN & K1 & K2 & K3 \\
\hline PMT 7A1 R & 4,80 & 342 & 35,07 \\
\hline PMT 7A1 S & 4,78 & 341 & 77,34 \\
\hline PMT 7A1 T & 4,88 & 338 & 65,98 \\
\hline PMT 7AB1 R & 4,69 & 335 & 65,09 \\
\hline PMT 7AB1 S & 4,70 & 345 & 43,87 \\
\hline PMT 7AB1 T & 4,75 & 340 & 33,45 \\
\hline
\end{tabular}

Rating kecocokan setiap alternatif pada setiap kriteria, dinilai dengan 1 sampai 4, yaitu :

$$
\begin{aligned}
& 1=\text { Darurat } \\
& 2=\text { Perbaikan Segera } \\
& 3=\text { Rencana Perbaikan } \\
& 4=\text { Normal }
\end{aligned}
$$

\section{Pembobotan Setiap Kriteria}

Pengambil keputusan memberi bobot preferensi dengan nilai $\mathrm{W}=3,3,2$. Adapun yang menjadi pembobotan setiap kriteria adalah sebagai berikut :

Tabel 2 Pembobotan Tekanan Gas SF6

\begin{tabular}{|c|c|c|}
\hline Tekanan Gas SF6 & Pembobotan & Nilai \\
\hline$>4,85$ & Normal & 4 \\
\hline $4,76-4,85$ & Rencana Perbaikan & 3 \\
\hline $4,66-4,75$ & Perbaikan Segera & 2 \\
\hline$<=4,65$ & Darurat & 1 \\
\hline
\end{tabular}

Tabel 3 Pembobotan Tekanan Hidrolik

\begin{tabular}{|c|c|c|}
\hline Tekanan Hidrolik & Pembobotan & Nilai \\
\hline$>=340$ & Normal & 4 \\
\hline $330-339$ & Rencana Perbaikan & 3 \\
\hline $320-329$ & Perbaikan Segera & 2 \\
\hline$<=319$ & Darurat & 1 \\
\hline
\end{tabular}

Tabel 4 Pembobotan Counter Kerja Pompa Hidrolik

\begin{tabular}{|c|c|c|}
\hline Counter KPH & Pembobotan & Nilai \\
\hline Counter KPH Bertambah & Normal & 4 \\
\hline
\end{tabular}


MJI Vol.12, No.2, Desember 2020, hlm. 61-68

\begin{tabular}{|c|c|c|}
\hline$<=0,25$ & & \\
\hline $\begin{array}{c}\text { Counter KPH Bertambah } \\
>0,25\end{array}$ & Darurat & 1 \\
\hline
\end{tabular}

$$
\begin{aligned}
& \mathrm{R}_{1,1}=\frac{\min (334222)}{3}=\frac{2}{3}=0,67 \\
& \mathrm{R}_{1,2}=\frac{\min (334222)}{3}=\frac{2}{3}=0,67 \\
& \mathrm{R}_{1,3}=\frac{\min (334222)}{4}=\frac{2}{4}=0,50 \\
& \mathrm{R}_{1,4}=\frac{\min (334222)}{2}=\frac{2}{2}=1 \\
& \mathrm{R}_{1,5}=\frac{\min (334222)}{2}=\frac{2}{2}=1 \\
& \mathrm{R}_{1,6} \frac{\min (334222)}{2}=\frac{2}{2}=1
\end{aligned}
$$

b. Untuk Tekanan Hidrolik termasuk kedalam atribut cost (biaya), karena semakin kecil nilai maka semakin baik.

$$
\begin{aligned}
& R_{2,1}=\frac{\min (333442)}{3}=\frac{2}{3}=0,66 \\
& R_{2,2}=\frac{\min (333442)}{3}=\frac{2}{3}=0,66 \\
& R_{2,3}=\frac{\min (333442)}{3}=\frac{2}{3}=0,66 \\
& R_{2,4}=\frac{\min (333442)}{4}=\frac{2}{4}=0,50 \\
& R_{2,5}=\frac{\min (333442)}{4}=\frac{2}{4}=0,50 \\
& R_{2,6}=\frac{\min (3334442)}{2}=\frac{2}{2}=1
\end{aligned}
$$

Tabel 6 Bobot Untuk Kriteria

\begin{tabular}{|l|c|c|}
\hline \multicolumn{1}{|c|}{ Kriteria } & Bobot & Nilai \\
\hline (K1) Tekanan Gas SF6 & Tinggi & 3 \\
\hline (K2) Tekanan Hidrolik & Tinggi & 3 \\
\hline $\begin{array}{l}\text { (K3) Counter Kerja Pompa } \\
\text { Hidrolik }\end{array}$ & Sedang & 2 \\
\hline
\end{tabular}

Dari tabel 4.6 diperoleh nilai bobot $(\mathrm{W})$ dengan data $\mathrm{W}=[$ $\left.\begin{array}{llll}3 & 3 & 2\end{array}\right]$.

Untuk menentukan bobot dari kriteria kondisi peralatan primer Gardu Induk dibentuk pada tabel berikut :

\section{Penggolongan Kriteria}

Untuk perhitungan matriks $\mathrm{R}$ membutuhkan penggolongan kriteria ke dalam nilai benefit atau cost, dimana benefit adalah keuntungan dan cost adalah biaya.

Tabel 4.7. Penggolongan Kriteria

\begin{tabular}{|c|c|c|}
\hline Kriteria & Cost & Benefit \\
\hline K1 & $\checkmark$ & - \\
\hline K2 & $\checkmark$ & - \\
\hline K3 & $\checkmark$ & - \\
\hline
\end{tabular}

7. Normalisasi matriks $\mathrm{X}$ menjadi matriks $\mathrm{R}$

Dalam menormalisasi matriks $\mathrm{X}$ menjadi matriks $\mathrm{R}$, yang harus dilakukan adalah menentukan nilai $\mathrm{R}$ dari masingmasing kriteria.

a. Untuk Tekanan Gas SF6 termasuk kedalam atribut cost (biaya), karena semakin kecil nilai maka semakin baik.

a. Untuk Counter Kerja Pompa Hidrolik termasuk kedalam atribut cost (biaya), karena semakin kecil nilai maka semakin baik.

$$
\begin{aligned}
& R_{4,1}=\frac{\min (232441)}{2}=\frac{1}{2}=0,50 \\
& R_{4,2}=\frac{\min (232441)}{3}=\frac{1}{3}=0,33 \\
& R_{4,3}=\frac{\min (232441)}{2}=\frac{1}{2}=0,50 \\
& R_{4,4}=\frac{\min (232441)}{4}=\frac{1}{4}=0,25 \\
& R_{4,5}=\frac{\min (232441)}{4}=\frac{1}{4}=0,25 \\
& R_{4,6}=\frac{\min (232441)}{1}=\frac{1}{2}=1
\end{aligned}
$$

Maka matriks R sebagai berikut :

$$
R=\left(\begin{array}{lll}
0,67 & 0,66 & 0,50 \\
0,67 & 0,66 & 0,33 \\
0,50 & 0,66 & 0,50 \\
1 & 0,50 & 0,25 \\
1 & 0,50 & 0,25 \\
1 & 1 & 1
\end{array}\right)
$$


8. Menentukan Rangking

Untuk mencari nilai dari masing-masing peralatandipakai rumus sebagai berikut :

$$
V_{i}=\sum_{j=1}^{n} W_{j} r_{i j}
$$

Keterangan :

$\mathrm{V}_{\mathrm{i}}=$ rangking untuk setiap alternatif

$\mathrm{W}_{\mathrm{j}}=$ nilai bobot dari setiap kriteria

$\mathrm{r}_{\mathrm{ij}}=$ nilai rating kinerja ternormalisasi

Jadi :

$$
\begin{aligned}
& V_{1}=3(0,67)+3(0,66)+2(0,50)=4,99 \\
& V_{2}=3(0,67)+3(0,66)+2(0,33)=4,65 \\
& V_{3}=3(0,50)+3(0,66)+2(0,50)=4,48 \\
& V_{4}=3(1)+3(0,50)+2(0,25)=5 \\
& V_{5}=3(1)+3(0,50)+2(0,25)=5 \\
& V_{6}=3(1)+3(1)+2(1)=8
\end{aligned}
$$

Dari hasil perhitungan nilai $\mathrm{V}_{\mathrm{i}}$ dari setiap peralatan, dapat dibuat tabel perangkingan sebagai berikut :

Tabel 7 Tabel Perangkingan

\begin{tabular}{|c|c|c|c|}
\hline NO. & KODE PERALATAN & NILAI & HASIL AKHIR \\
\hline 1 & PMT 7AB1 T & 8 & Darurat \\
\hline 2 & PMT 7AB1 R & 5 & Perbaikan Segera \\
\hline 3 & PMT 7AB1 S & 5 & Perbaikan Segera \\
\hline 4 & PMT 7A1 R & 4,99 & Perbaikan Segera \\
\hline 5 & PMT 7A1 S & 4,65 & Perbaikan Segera \\
\hline 6 & PMT 7A1 T & 4,48 & Perbaikan Segera \\
\hline
\end{tabular}

Dari penentuan prioritas kondisi peralatan dengan menggunakan metode simple additive weighting maka peralatan yang memiliki kondisi terburuk adalah PMT 7AB1 T karena memiliki nilai yang lebih tinggi dengan hasil akhir darurat. Hasil Akhir dihitung berdasarkan perkiraan kondisi terbaik dan terburuk. Jika nilainya 8 maka hasil akhirnya darurat, jika nilainya $<8$ dan $>2$ maka hasil akhirnya perbaikan segera, dan jika nilainya 2 maka hasil akhirnya normal.

\subsection{Analisis Permodelan}

Berikut ini merupakan use case diagram dan Class diagram dari Sistem Pendukung Keputusan Pemeriksaan Kondisi Peralatan Primer Gardu Induk Berbasis Mobile Dengan Menggunakan Metode SAW di PT. PLN (PERSERO) GITET Saguling.

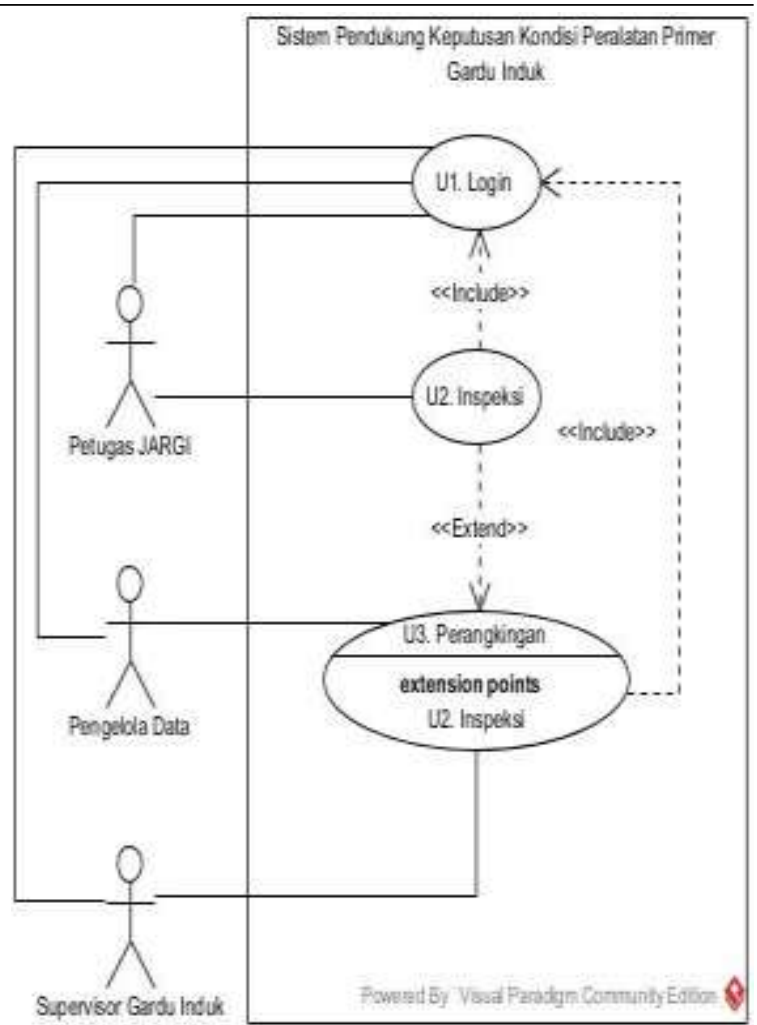

Gambar 2 Use Case Diagram Sistem Pendukung Keputusan Pemeriksaan Kondisi Peralatan Primer Gardu Induk Berbasis Mobile.

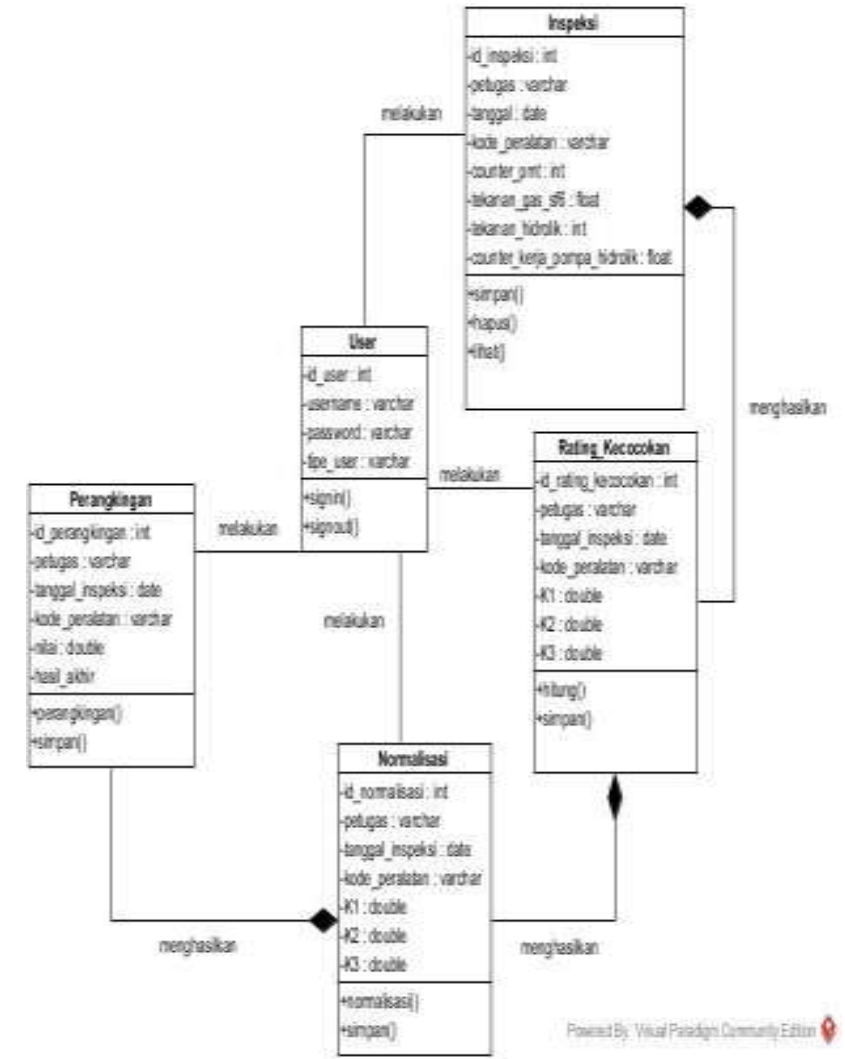

Gambar 3 Class Diagram Sistem Pendukung Keputusan Pemeriksaan Kondisi Peralatan Primer Gardu Induk Berbasis Mobile. 


\subsection{Hasil Implementasi}

1. Halaman Splash Screen

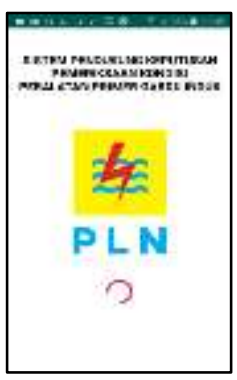

Gambar 4 Halaman Splash Screen

Halaman Splash Screen adalah halaman yang muncul sementara sebelum masuk kedalam aplikasi. Tampilan ini menampilkan nama aplikasi, logo dan icon progress.

\section{Halaman Login}

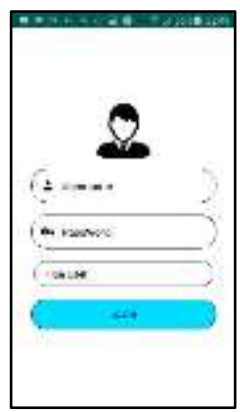

Gambar 5 Halaman Login

Halaman login menampilkan logo user, Edit Text username, Edit Text password dan tombol login. Edit Text username untuk memasukkan username, Edit Text password untuk memasukkan password dan tombol login untuk memverifikasi data supaya dapat masuk ke halaman utama.

3. Halaman Utama Petugas JARGI

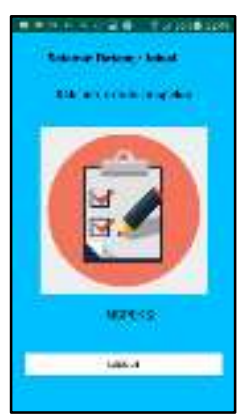

Gambar 6 Halaman Utama Petugas JARGI

Halaman utama petugas JARGI menampilkan foto user, nama user, sebuah text informasi bahwa user harus menekan icon jika ingin memulai inspeksi, sebuah icon inspeksi, dan tombol logout.
4. Halaman Inspeksi

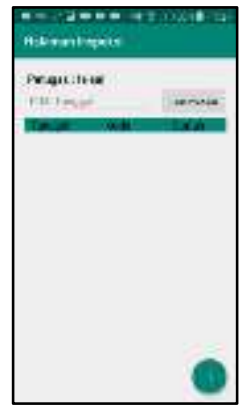

Gambar 7 Halaman Inspeksi Sebelum Memilih Tanggal

Halaman Inspeksi sebelum memilih tanggal menampilkan nama petugas, edittext pilih tanggal, tombol tampilkan dan tombol tambah data. Jika ingin menambah data, user harus menekan tombol tambah data. Jika ingin melihat data, pilih tanggal dan klik tombol tampilkan.

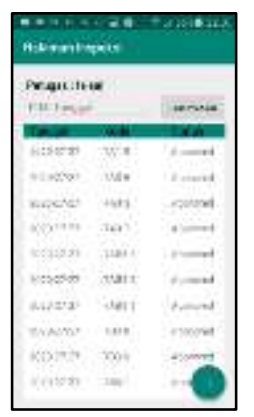

Gambar 8 Halaman Inspeksi Setelah Memilih Tanggal

Halaman Inspeksi setelah memilih tanggal menampilkan nama petugas, edittext pilih tanggal, tombol tampilkan dan tombol tambah data. Jika ingin menambah data, user harus menekan tombol tambah data. Jika ingin mengubah data atau menghapus data, user harus menekan listview. Jika ingin menampilkan data berdasarkan tanggal, pilih tanggal dan klik tombol tampilkan.

\section{Halaman Formulir Inspeksi}

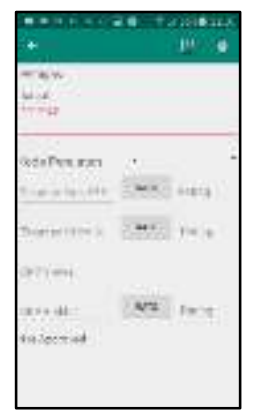

Gambar 9 Halaman Formulir Inspeksi

Halaman Formulir Inspeksi menampilkan Edit Text untuk menambahkan data, tombol simpan dan tombol hapus. 
6. Halaman Utama Pengelola Data

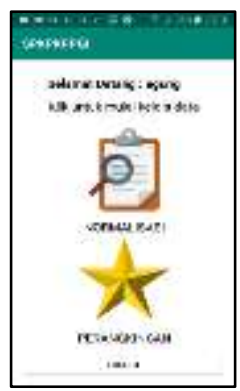

Gambar 10 Halaman Utama Pengelola Data

Halaman Utama Pengelola Data menampilkan nama user, text informasi bahwa user harus menekan icon normalisasi atau perangkingan jika ingin memulai normalisasi atau perangkingan.

\section{Halaman Normalisasi}

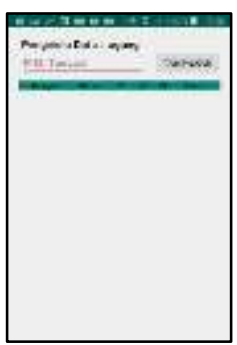

Gambar 11 Halaman Normalisasi Sebelum Memilih Tanggal

Halaman Normalisasi sebelum memilih tanggal menampilkan nama pengelola data, edittext tanggal dan tombol tampilkan.

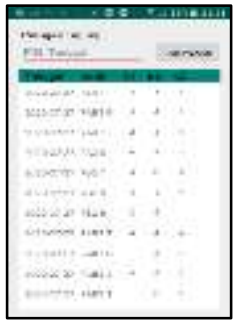

Gambar 12 Halaman Normalisasi Setelah Memilih Tanggal

Halaman Normalisasi setelah memilih tanggal menampilkan nama pengelola data, edittext tanggal dan tombol tampilkan serta listview.

\section{Halaman Hitung Normalisasi}

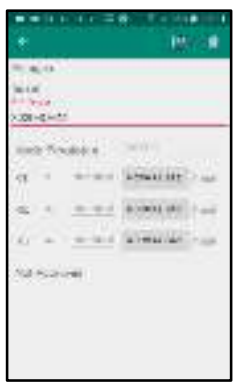

Gambar 13 Halaman Hitung Normalisasi
Halaman Hitung Normalisasi digunakan untuk menghitung data normalisasi kondisi peralatan primer Gardu Induk.

9. Halaman Perangkingan

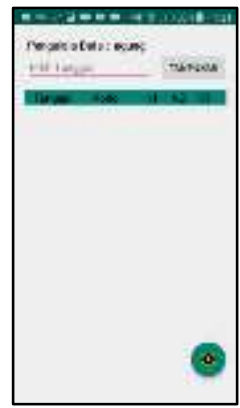

Gambar 14 Halaman Perangkingan Sebelum Memilih Tanggal

Halaman Perangkingan sebelum memilih tanggal menampilkan nama pengelola data, edittext tanggal, tombol tampilkan dan tombol lihat perangkingan.

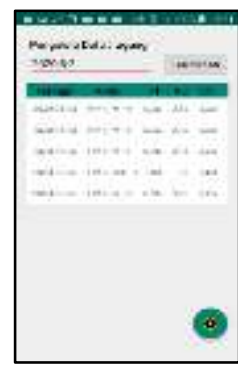

Gambar 15 Halaman Perangkingan Setelah Memilih Tanggal

Halaman Perangkingan menampilkan nama pengelola data, tombol lihat perangkingan, edittext tanggal, tombol tampilkan dan data normalisasi kondisi peralatan primer Gardu Induk yang selanjutnya akan dilakukan perhitungan perangkingan.

10. Halaman Hitung Perangkingan

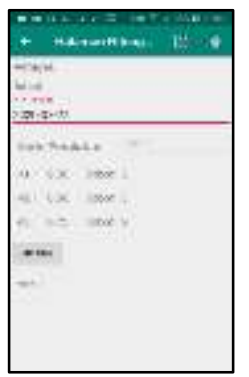

Gambar 16. Halaman Hitung Perangkingan

Halaman Hitung Perangkingan digunakan untuk menghitung data perangkingan kondisi peralatan primer Gardu Induk. 
11. Halaman Lihat Perangkingan

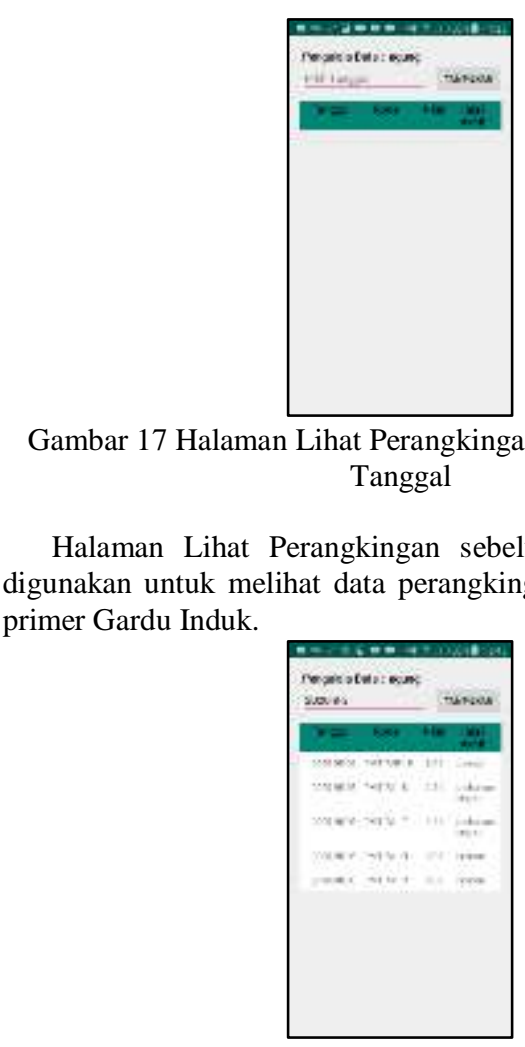

Gambar 18 Halaman Lihat Perangkingan Setelah Memilih Tanggal

Halaman Lihat Perangkingan setelah memilih tanggal digunakan untuk melihat data perangkingan kondisi peralatan primer Gardu Induk.

\section{Kesimpulan}

Dari hasil penelitian, perancangan dan implementasi yang telah dilakukan maka dapat disimpulkan bahwa Sistem Pendukung Keputusan Pemeriksaan Kondisi Peralatan Primer Gardu Induk Berbasis Mobile Dengan Menggunakan Metode SAW di PT. PLN (PERSERO) GITET Saguling dapat mempermudah dalam pendataan dan pelaporan data kondisi peralatan primer Gardu Induk, dapat melakukan assesment peralatan Gardu Induk., membuat pekerjaan menjadi lebih efektif karena tidak perlu mengisi data checklist di kertas dan efisiensi pengguna karena Supervisor GI tidak perlu melakukan approval hanya menerima hasil akhir perangkingan.

\section{Daftar Pustaka}

[1] Pressman, R.S., Rekayasa Perangkat Lunak: Pendekatan Praktisi Buku I. Yogyakarta: Andi.. 2015.

[2] Kusrini. Konsep dan Aplikasi Sistem Pendukung Keputusan. Andi Offset. Yogyakarta. 2007.

[3] Hartono, Bambang. 2013. Sistem Informasi Manajemen Berbasis Komputer. Jakarta: Rineka Cipta.

[4] Asnawati, Indra Kanedi. 2012. Sistem Pendukung Keputusan Kenaikan Pangkat Karyawan Perseroan Terbatas Pelayaran Kumafa Lagun Marina Bengkulu. ISSN: 1858-2680. Bengkulu: Jurnal Media Infotama Vol.8, No. 1 Februari 2012: 118137

[5] Munthe, Hotmaria Ginting. 2013. Sistem Pendukung Keputusan Penentuan Prioritas Usulan Sertifikasi Guru Dengan Metode Simple Additive Weighting. ISSN: 2301-9425. Medan: Pelita Informatika Budi Darma Vol IV, No. 2 Agustus 2013: 52-58.

[6] PERDIR PT. PLN (Persero). 2018. Susunan Organisasi dan Formasi Jabatan PT PLN (Persero) Unit Layanan Transmisi dan Gardu Induk Bandung Barat pada PT PLN (Persero) Unit Pelaksana Transmisi Bandung. 